\title{
RESPONSABILIDADE CORPORATIVA DAS PEQUENAS E MÉDIAS EMPRESAS NA ERA GLOBAL
}

\section{MARCELO DE OLIVEIRA BUSATO}

Aluno especial do curso de Mestrado - Centro Universitário Curitiba - UNICURITIBA. Curitiba - PR. E-mail: marcelo_busato@hotmail.com

\section{RESUMO}

As pequenas e médias empresas, embora sejam a grande maioria das organizações empresarias, são desconsideradas nos debates públicos (ENDERLE). A responsabilidade corporativa não é só possível mas também necessária para que as PME consigam seu lugar no sistema da economia global. Sabe-se que, $p$ Enderle resume 4 pontos de dificuldades para as PMES: 1) alta concorrência; 2) tamanho pequeno das PMES em relação às empresas grandes; 3) as PMES estão mais preocupadas com a própria sobrevivência do que em relação da ética; 4) A relevância da ética seria bem menor para as PME do que para as empresas grandes. Como sugestão de soluções poderíamos citar: 1) sustentável em termos econômicos, sociais e ambientais; 2) Comprometimento com você mesmo, como empresário, e depositando uma grande confiança em seu pessoal, trabalhadores e clientes; 3) Desenvolvimento de uma coordenação excelente em seu produto, sua companhia e o contexto local, para chegar a ser competitivo em nível global; 4) Busca do processo de aprendizagem e implementação com abertura e perseverança, passo a passo; 5) Utilização de seu espaço de liberdade para um maior e mais extenso cumprimento, por meio de criação de redes com sócios que compartilhem os mesmos pensamentos e sentimentos; 6) Respeito para com a tripla conta de resultados das responsabilidades econômicas, sociais e do meio ambiente com o correspondente equilíbrio dessas responsabilidades para maximizar a sustentabilidade; 7) Avaliação 
Personalidade Acadêmica Homenageada:

Raymundo Juliano Feitosa (Universidade Federal do Rio Grande do Norte - UFRN)

de seu negócio por auditores independentes em termos de capacidades, tornando significativo até que ponto você contribui para ampliar as liberdades reais de que as pessoas desfrutam. Com efeito, "investir na microempresa e empresa de pequeno porte é gerar distribuição de riquezas, disponibilizar postos de trabalho, melhorar a qualidade de vida das regiões que a sediam, promover a sustentabilidade e inclusão social." 1

PALAVRAS-CHAVE: Responsabilidade Corporativa; Pequenas e Médias Empresas; Globalização.

\section{REFERÊNCIAS}

LORGA, Marco Antonio. Direito Empresarial e Desenvolvimento Social: Políticas Públicas para Micro e Pequenas Empresas. Revista Jurídica UNICURITIBA. 2012.

ENDERLE, Georges. Direito empresarial e desenvolvimento social: políticas públicas para micro e pequenas empresas, in COERTINA, Adela. "Construir Confiança". São Paulo, ed. LOYOLA, 2007.

ROSSETTI, José Paschoal. Introdução à Economia. 19. ed. São Paulo: Atlas, 2002.

\footnotetext{
${ }^{1}$ LORGA, Marco Antonio. Direito Empresarial e Desenvolvimento Social: Políticas Públicas para Micro e Pequenas Empresas. Revista Jurídica UNICURITIBA. 2012.
} 